\title{
Bicentenary of the Staffordshire General Infirmary
}

\author{
J. MACD. HOLMES, M.D., F.R.C.P.
}

Brit. med. F., 1966, 2, 1064-1065

\begin{abstract}
On 4 November the Staffordshire General Infirmary at Stafford is due to commemorate the bicentenary of its foundation. At the first ceremony Professor Max Rosenheim, P.R.C.P., will open a new medical litrary, which has been formed in the original board room of the hospital and contains some early furniture dating from the hospital's foundation. The Infirmary had close links with the Lunar Society of Birmingham (B.M.J., 15 Ocrober, p. 945). Two of its early physicians-Erasmus Darwin and William Withering-were members of the Society, and eventually in 1775 Withering moved to Birmingham to become the partner of another member, Dr. Fohn Ash.
\end{abstract}

The 1760 s were productive years in the Midlands, marked by an upsurge of scientific curiosity and industrial enterprise, which found their most distinguished expression in the work of the members of the Lunar Society. Medicine was included in this scientific progress and was reflected in an awakening interest among the landed gentry in the care of the sick.

It was their initiative which led to the formation of the Staffordshire General Infirmary in 1766. At about the same time hospitals at Birmingham, Leicester, and Worcester were begun, following the example of those founded in Manchester and Chester a few years earlier.

The first meeting for discussing the establishment of the hospital at Stafford took place on 8 October 1765 . John Eld, of Seighford Hall, was the most active member, supported by Richard Whitworth, the M.P. for Stafford, the Lord Lieutenant (Earl Gower), Lord $\mathrm{St}$ a $\mathrm{m} \mathrm{f}$ ord, and Lord Dudley.

John Eld's efforts were later commemorated in a portrait by Gainsborough, painted in 1772, which hung in the hospital board-room until 1912. This was sold at Christie's for 4,000 guineas in order to raise funds for the hospital's depleted exchequer. A good copy hangs in its place, and the original is in the Boston City Museum.

\section{Establishment}

In December 1765, after the board of trustees had been chosen and a weekly committee of management set up, the hospital was established in a house in Foregate Street, which had been leased for 10 years. A few months later a neighbouring house was bought by John Eld, and the two were equipped for use as a hospital, the first being for women patients and the second for men.

The purchase of equipment was made by the weekly board, which began its meetings in 1766 ; the detailed records still exist. A set of six chairs in the Chinese taste and certainly copied from Chippendale's designs in his Gentleman and Cabinet Maker's Directory by a local cabinet maker, Mr. Bickley, still form part of the furniture of the board-room.
There were 34 beds in the two houses, and patients were first admitted on 27 June 1766 . Only 27 patients were admitted between this date and October, and 19 outpatients were treated in the same period. The hospital's popularity grew, however, and in March 1768 it was decided to purchase a site for a new building, a committee being appointed for this purpose.

In January the following year Stafford Corporation offered to lease to the trustees some land in Foregate Street at a nominal rent of 8 shillings a year for 500 years, and in August 1769 a tender was accepted from Benjamin Wyatt and Sons to build the new infirmary for $£ 2,784$.

The work was finished in 1771. A contemporary engraving shows a plain symmetrical building with a three-storeyed central block and two-storeyed wings on either side (see Fig.). The central block retains its original internal structure today.

The building originally accommodated 80 patients, and no appreciable increase in its size was made until 1896. New operatingtheatres were built in 1920 , a nurses' home was added in 1927, new casualty and outpatient buildings in 1930, and in 1938 a large new block containing an $x$-ray department. No further addition was made until 1953, when new pathological laboratories were added, together with an orthopaedic ward, at a cost of $£ 80,000$. In 1773 , the first full year of use of the new building, the number of inpatients treated was 151 ; in 1965 the number had grown to 5,481 .

The architect and builder, Beniamin Wyatt (1709-72), was born at Weeford, and was originally a farmer and timber merchant. He had seven sons, of whom the most famous was James, but the one most active in Staffordshire was Samuel; he is known to have been working at Blithfield Hall in the late 1760s. The eldest brother, William, of whom little is known, was consulted by Matthew Boulton about designs for Birmingham General Hospital in 1766.

\section{William Withering}

The hospital's first physicians were William Withering and Archibald Campbell, and the first surgeons Thomas Wright 


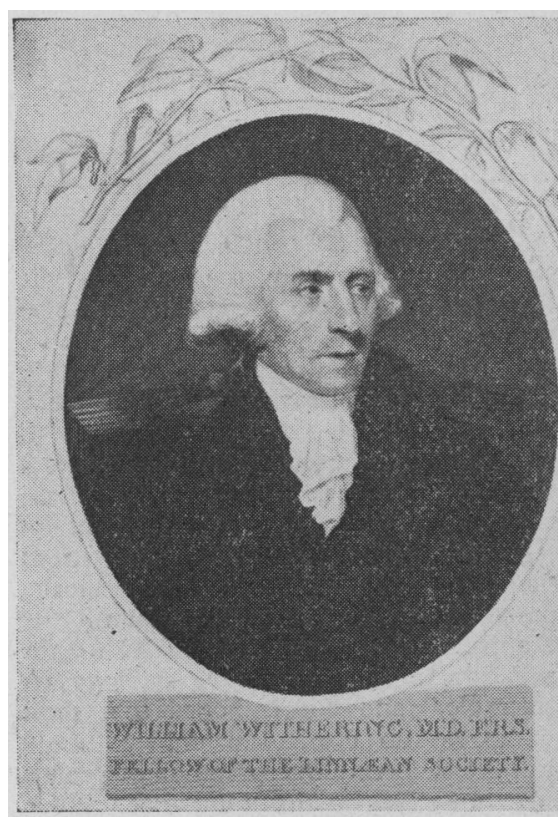

Willam Withering.

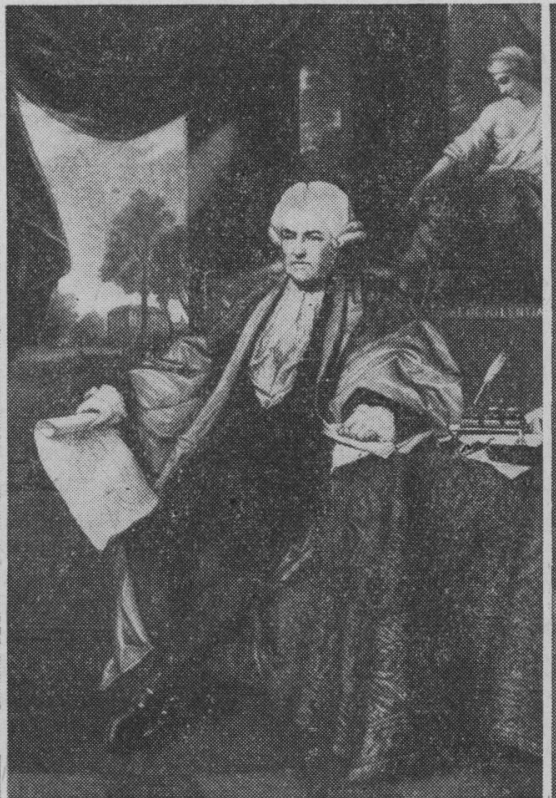

Jonu Ash.

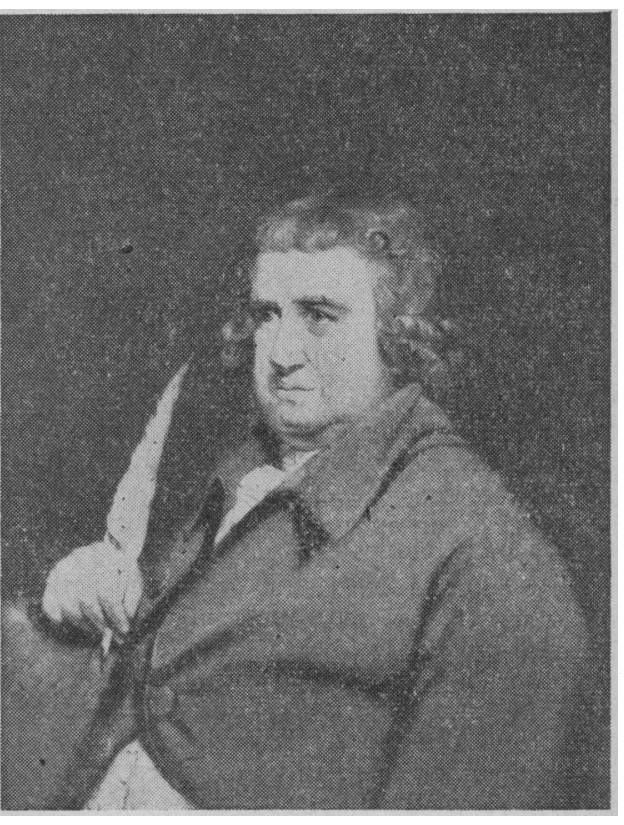

Erasmus Darwin. and John Ward. William Withering (1741-99) was one of the greatest figures in English medicine in the eighteenth century. Birmingham usually claim him as their own, but the first eight and a half years of his professional life after graduation were spent in Staflord, and it was there that he made his first observations on the effects of digitalis in the treatment of congestive heart fallure. He tells us that although he first used the drug at Stafford he had much greater opportunity of testing it in his larger clinics after he moved to Birmingham. Withering thought the action of digitalis was upon the kidney. At first there was no way of calculating the dose, and he encountered alarming toxic reactions, but he eventually found that, when the foxglove leaves were collected green, 3 drachms of the powdered leaves boiled in 8 to 12 ounces of water and given in two spoonfuls every hour until nausea developed usually produced a profound diuresis and an improvement in the patient's sense of well-being, with a slowing of the pulse and an increase in its volume. After this dosage the medicine was stopped for three or four days.

The publication of the effects of digitalis caused an estrangement between Withering and his friend Erasmus Darwin, of Lichfield, who had persuaded him to leave Stafford for Birmingham in 1775. The story cannot be related here, but although Darwin did precede Withering in publication it seems probable that he took advantage of his knowledge of Withering's use of the drug.

In the hospital accounts for September 1766 there is mention of the purchase of an "electric machine" for use by Dr. Withering. This was probably a variant of the glass frictional machine introduced by Hauksbee in 1709. These machines were popular scientific toys in the eighteenth century, and although the electrical discharge obtainable must have been very feeble it is known that Withering used it for peripheral-nerve stimulation in cases of lead palsy. He thought that this stimulation had some therapeutic effect; but, unlikely as this may be, it is an indication of his inquiring mind and of an early study in electrophysiology. His years in Stafford gave him ample opportunity to study botany, and during this time he wrote his two volumes, Botanical Arrangement of Vegetables, which earned him the title of the "English Linnaeus." He was also well known as a mineralogist, and a naturally occurring form of barium carbonate is named "Witherite" after him. Indeed, he was better known on the Continent as a botanist and mineralogist than for his work on digitalis. He attended meetings of the Royal Society as a guest in 1766, and was elected a Fellow in 1779. He was also a member of the Linnaean Society and of the Medical Suciety of London. The only known portrait of him-in 1792, by von Breda, who worked in England in the 1790s-now hangs in the Stockholm National Gallery.

In 1775 , on the death of Dr. Small, Withering was invited to go to Birmingham, where he became a partner of Dr. Ash and a member of the Lunar Society. He made weekly visits to Stafford for a time, and later Dr. Erasmus Darwin undertook some of his dutses in Stafford until the appointment of Dr. Thomas Fowler (1736-1801), who introduced liquor arsenicalis ("Fowler's solution") into therapeutics ("Medical reports of the effects of arsenic in the case of agues, remitting fevers, and periodic headaches"). This was tremendously popular as a remedy in the nineteenth century in spite of its uselessness and toxic properties.

In 1838 Edward Selleck Hare was a house-surgeon at the hospital, and he is notable for the first description of cervical sympathetic paralysis in a very succinct clinico-anatomical account of a man who died of a tumour in the neck. This description recorded the constriction of the pupil and drooping of the eyelid, later known as Horner's syndrome after Johann Friedrich Horner (1831-86), in a letter to the Medical Gazette dated 11 September 1838. Hare died tragically of typhus, contracted in the hospital, on 28 September 1838 at the age of 26. He did not realize that the signs he mentioned were those of sympathetic paralysis, but he should have credit for the first description of the syndrome later associated with the names of Claude Bernard and Horner.

Today the hospital serves a population of about 200,000 and is the central establishment of a group of hospitals containing about 900 beds. In spite of the additions which have been mentioned a large proportion of the premises is antiquated and inadequate. An entirely new Staffordshire General Infirmary of $600-800$ beds is envisaged in the future plans of the Birmingham Regional Hospital Buard, but for many years the work of the hospital will have to continue in the building I have described.

The portraits are printed by permission of the Wellcame Historical Medical Museum. 